\title{
EFIKASI GRANUL BIOLARVASIDA NYAMUK AEDES AEGIPTY DARI EKSTRAK ETIL ASETAT DAUN BELUNTAS
}

\section{(THE EFFICATION OF AEDES AEGYPTI BIOLARVASIDA GRANUL FROM ETIL ACETAT EXTRACT OF MARSH FLEABANE LEAVES)}

\author{
Agus Rochmat, Mita Napitasari, dan Afdwiyarni Metta Karina \\ Fakultas Teknik Universitas Sultan Ageng Tirtayasa \\ J1. Raya Jak Km.4, Panancangan Serang Banten 42124 \\ email: agus_rochmat@untirta.ac.id
}

\begin{abstract}
Abstrak
Penelitian ini bertujuan untuk mengetahui aktivitas dari ekstrak daun beluntas terhadap mortalitas larva nyamuk Aedes aegypti. Ekstrak daun beluntas diperoleh dengan menggunakan metode ekstraksi pada pelarut etanol. Setelah didapatkan ekstrak kental, maka ekstrak tersebut difraksinasi dengan pelarut n-heksana dan etil asetat. Kemampuan biolarvasida ekstrak daun beluntas ditentukan melalui nilai $\mathrm{LC}_{50}$ dan diperkuat dengan identifikasi kandungan senyawa aktif. Uji biolarvasida ini dilakukan terhadap larva nyamuk Aedes aegypti dengan variasi konsentrasi ekstrak 50, 100, 250, 500, dan 1000 ppm selama 24 jam pengamatan. Identifikasi kandungan senyawa dilakukan dengan pengujian sampel dengan analisa GC-MS. Hasil penelitian menjunjukkan bahwa rendemen ekstrak etil asetat sebesar 1,86 $\%$. Nilai $\mathrm{LC}_{50}$ ekstrak etil asetat ini adalah $105,79 \mathrm{ppm}$. Nilai $\mathrm{LC}_{50}$ yang diperoleh termasuk golongan biolarvasida aktif dan kontrol positif menggunakan abate memiliki nilai $\mathrm{LC}_{100}$ pada konsentrasi $100 \mathrm{ppm}$. Sementara itu, nilai $\mathrm{LC}_{50}$ pada granul dengan kandungan ektrak daun beluntas yang terbaik diperoleh nilai 96,34 ppm dan nilai $\mathrm{LC}_{90}$ adalah $905.1 \mathrm{ppm}$. Kemampuan biolarvasida aktif ekstrak beluntas ini dikuatkan dengan hasil analisa GC-MS yang menunjukkan bahwa kandungan senyawa aktif biolarvasida yang terkandung dalam ekstrak etil asetat diduga asam quanat.
\end{abstract}

Kata kunci: etil asetat, ekstrak beluntas, biolarvasida, $L C_{50}$, asam quanat

\begin{abstract}
This study was aimed at determining the activity of Marsh Fleabane leaves extract against Aedes aegypti mosquito larvae mortality. Marsh Fleabane leaves extract was obtained using ethanol solvent. After obtaining the viscous extract, the extract was fractionated with solvent n-hexan and ethyl acetate. The ability of this biolarvaside was determined by $L C_{50}$ value and reinforced by identifying of active compound content. This biolarvaside test was conducted on Aedes aegypti mosquito larvae with variation of extract concentration 50, 100, 250, 500, and 1000 ppm during 24 hours observation. Identification of compound content was done by testing the sample with GC-MS analysis. The results show that the yield of ethyl acetate extract equal to $1.86 \%$. The LC value of this ethyl acetate extract was $105.79 \mathrm{ppm}$. The obtained $L C_{50}$ values including active biolarvacidal groups and positive controls using abate had $L C_{100}$ values at 100 ppm concentrations. Meanwhile, the $L C_{50}$ value
\end{abstract}


on granules using marsh Fleabane leaves extract content was obtained at $96.34 \mathrm{ppm}$ and $L C_{90}$ was $905.1 \mathrm{ppm}$. The ability of active biolarvaside is corroborated by $G C$ $M S$ analysis results indicating that the biolarvacid content of active compounds contained in ethyl acetate extract expected as quinic acid.

Keywords: ethyl acetate, Marsh Fleabane extract, biolarvasida, LC50, Quinic Acid

\section{PENDAHULUAN}

Kasus demam berdarah dengue (DBD) di Kota Cilegon merupakan yang tertinggi di Banten bila jumlah kasus dirata-ratakan dengan jumlah penduduk yang ada. Di Provinsi Banten angka kesakitan DBD berada di kisaran 55 orang per 100 ribu jumlah penduduk, sementara di Kota Cilegon angka kesakitan DBD masih di atas 100 orang per 100 ribu jumlah penduduk. Data Dinkes Cilegon sampai Juni tahun ini sudah ada 233 kasus DBD atau mencapai 61 angka kesakitan dari 100 ribu jumlah penduduk (Kasus DBD, 2013).

Penyakit DBD disebabkan oleh virus dengue yang disebarkan oleh nyamuk Aedes aegypti. Selain membawa virus dengue, Aedes aegypti juga merupakan pembawa virus demam kuning (yellow fever) dan chikungunya. Pemberantasan nyamuk Aedes aegyptisangat sulit karena mereka memiliki kemampuan adaptasi lingkungan yang membuat mereka sangat tangguh, bahkan setelah gangguan akibat fenomena alam (kekeringan, misalnya) atau intervensi manusia (misalnya tindakan pengendalian). Salah satu adaptasi tersebut adalah kemampuan telur untuk bertahan di kondisi ekstrim.

Penggunaan insektisida sintetik memang efektif untuk membunuh larva nyamuk. Namun, penggunaan insektisida sintetik secara kontinyu dapat menyebabkan dampak negatif seperti polusi lingkungan (kontaminasi tanah, air, dan udara), serangga hama menjadi resisten, resurgen maupun toleran terhadap pestisida, serta dampak negatif lainnya (Kardinan, 2011). Adanya dampak negatif dari penggunaan insektisida kimia memunculkan penelitian baru dalam pengendalian siklus hidup nyamuk yang lebih aman, sederhana, dan berwawasan lingkungan yaitu salah satunya adalah insektisida nabati. Insektisida nabati merupakan salah satu sarana pengendalian hama alternatif yang layak dikembangkan, karena senyawa insektisida dari tumbuhan mudah terurai di lingkungan, tidak meninggalkan residu di udara, air dan tanah serta mempunyai tingkat keamanan yang lebih tinggi bila dibandingkan dengan racunracun anorganik.

Indonesia merupakan salah satu negara berkembang yang mempunyai banyak 
sumberdaya alam diantaranya sumberdaya alam hayati. Beluntas (Pluchea indica Less) merupakan tanaman herba famili Asteraceae yang telah dimanfaatkan sebagai pangan dan sediaan obat bahan alam. Beluntas telah lama dikenal mempunyai banyak kegunaan baik sebagai tanaman pagar maupun tanaman obat dengan menggunakan seluruh bagian tanamannya dalam bentuk kering maupun segar. Sifat antimikroba daun beluntas telah dilaporkan oleh Ardiansyah (2003). Senyawa aktif yang diduga berperan sebagai senyawa antimikroba pada ekstrak daun beluntas adalah fenol hidrokuinon, tanin, dan alkanoid. Berdasarkan informasi diatas, perlu kiranya dilakukan penelitian terhadap aktivitas biolarvasida tanaman beluntas pada larva nyamuk Aedes aegypti.

\section{METODE PENELITIAN}

Alat yang digunakan adalah rotary evaporator, ekstraktor Soxhletasi, oven vacuum, Sonikator.

Bahan yang digunakan adalah aquadest, daun Beluntas (Balitro Bogor), larva Aedes aegypti (Fakultas Kedokteran Hewan IPB), pelarut etil asetat, aqua bidestilata, aluminium foil, dan tissue.

Pembuatan ekstrak daun beluntas kental ini mengacu pada BPOM 2004 dengan beberapa modifikasi. Daun beluntas mula-mula dibersihkan, dicuci dengan air, dan dikeringkan. Daun beluntas selanjutnya dihaluskan dengan blender dan diayak 20 mesh. Serbuk daun beluntas diekstraksi secara maserasi dengan pelarut etil asetat. Filtrat yang diperoleh diuapkan menggunakan rotary evaporator hingga diperoleh ekstrak kental dan dipanaskan di vacum oven pada suhu $50^{\circ} \mathrm{C}$ selama $18 \mathrm{jam}$.

Pengujian biolarvasida mengacu pada Bhawan dan Nagar (2012) dengan beberapa modifikasi teknis. Larutan uji dimasukkan ke dalam tabung reaksi dengan replikasi sebanyak 3 kali untuk setiap konsentrasi. Pada masing-masing tabung reaksi tersebut dimasukkan 10 larva. Inkubasi dilakukan selama 1x24 jam. Kemudian dilakukan pengamatan terhadap larva yang mati dan dihitung harga $\mathrm{LC}_{50}$.

Nilai toksisitas $\left(\mathrm{LC}_{50}\right)$ diolah dari data pada pengujian anti larva nyamuk yang dilakukan dengan analisis probit menggunakan software microsoft excel, sedangkan perhitungan $\mathrm{LC}_{50}$ menggunakan persamaan garis $y=a x+b$ dengan nilai mortalitas sebagai garis y dan nilai logaritma konsentrasi sebagai garis $\mathrm{x}$. $\mathrm{LC}_{50}$ dihitung dengan mortalitas sebesar $50 \%$ yakni pada $\mathrm{y}=0,5$.

Pembuatan granul biolarvasida mengacu pada Reiza (2010) dengan beberapa modifikasi metode. Ekstrak daun beluntas yang diperoleh kemudian dilakukan penambahan bahan inert sebagai penstabil yang terdiri dari 10\% bahan aktif (ekstrak 
daun beluntas), dan komposisi inert (45\% laktosa, $3 \%$ amilum, $1 \%$ magnesium stearat, dan $1 \%$ polivinil piropidol). Kemudian dilakukan pembentukan granul dengan metode granulasi basah menggunakan pelarut etanol dana ayakan 20 mesh. Granul yang telah diperoleh kemudian dioven pada temperatur $40^{\circ} \mathrm{C}$ selama2 jam. Karakteristik granul dilakukan beberapa pengujian seperti: uji kestabilitas, uji kelarutan dalam air, uji organoleptik, dan uji efikasi terhadap larva.

\section{HASIL DAN PEMBAHASAN}

Proses ekstraksi yang dilakukan pada penelitian ini adalah dengan metode ekstraksi maserasi menggunakan pelarut etil asetat teknis dengan perbandingan simplisia dengan pelarut adalah 1:5. Proses maserasi dilakukan dengan bantuan ultrasonikator selama 15 menit. Proses pengadukan dilakukan dengan tujuan mengoptimalkan proses difusi pelarut kedalam simplisia dan dilakukan dalam waktu yang relatif singkat. Hasil ekstraksi yang diperoleh seperti terdapat pada Gambar 1.

Rendemen yang diperoleh pada proses maserasi adalah $1,86 \%$. Untuk mendapatkan ekstrak kental daun beluntas, dilakukan pemanasan di vacuum oven pada suhu $50^{\circ} \mathrm{C}$ selama 18 jam. Ekstrak kental siap dilakukan uji biolarvasida.

Telur nyamuk Aedes aegypti dapat bertahan dalam kondisi kering hingga 6
Gambar 1. Hasil Ekstraksi (a) Hasil Maserasi Ultrasonikator; (b) Hasil Pemekatan dengan Rotary Evaporator; (c) Ekstrak Kental

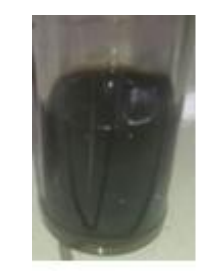

(a)

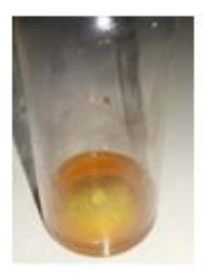

(b)

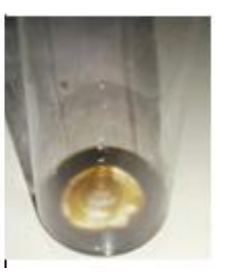

(c) bulan, akan tetapi akan menetas dalam 2 jam apabila berkontak dalam air. Pertumbuhan larva nyamuk Aedes aegypti akan berlangsung baik pada temperatur ruang $\left(25-30^{\circ} \mathrm{C}\right)$. Kenampakan pertumbuhan larva menggunakan mikroskop cahaya ditunjukkan pada Gambar 2.

Gambar 2. Pertumbuhan Larva Nyamuk Aedesaegypti: (a) Telur Nyamuk; (b) Larva Instar I; (c) Larva Instar II; (d) Larva Instar III

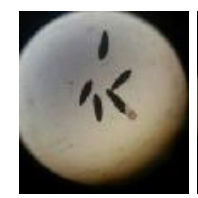

(a)

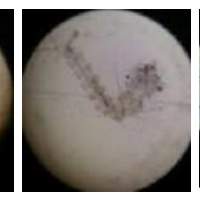

(b)

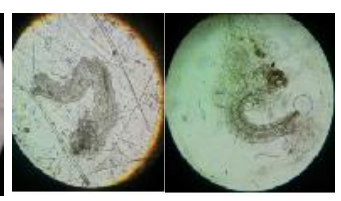

(c) (d)
Telur nyamuk Aedes aegypti dapat dilihat menggunakan mata telanjang dengan bentuk lonjong dan berwarna hitam. Larva instar I diperoleh setelah 2 jam telur berada 
dalam air dan menetas menjadi larva kecil. Larva instar I memiliki panjang tubuh 1 $\mathrm{mm}$. Larva I tumbuh menjadi larva instar II dalam 1 hari. Larva isntar II memiliki panjang 2,5-3,9 mm. Dari larva instar II akan tumbuh menjadi larva instar III selama 1-2 hari. Larva instar III berukuran panjang $4 \mathrm{~mm}$. Pada larva instar III inilah yang akan digunakan untuk pengujian efikasi granul biolarvasida.

Pada proses pembuatan granul biolarvasida dibutuhkan penambahan bahan tambahan lain. Pemilihan bahan tambahan yang akan digunakan harus memperhatikan sifat-sifat bahan tambahan tersebut, yaitu harus inert, tidak berbau, tidak berasa dan jika mungkin tidak berwarna (Voight, 1994). Bahan tambahan terdiri dari bahan pengisi dan bahan pengikat. Laktosa bertugas sebagai pengisi, sedangkan pati (amilum), magnesium stearat dan polivinil piropidol (PVP) memiliki fungsi sebagai pengikat. Komposisi bahan granul disajikan pada Tabel 1 didasarkan pada (Voight, 1994).

Tabel 1

Komposisi Bahan Granul

\begin{tabular}{lc}
\hline \multicolumn{1}{c}{ Bahan } & Kuantitas \\
\hline Laktosa & $45 \%$ \\
Amilum & $3 \%$ \\
Magnesiumstearat & $1 \%$ \\
PVP & $1 \%$ \\
\hline
\end{tabular}

Metode pembuatan granul biolarvasida adalah granulasi basah dengan penambahan etanol sebagai pelarut untuk memperoleh campuran bahan inert dan ekstrak agar dapat saling mengikat dan membentuk gumpalan dan dicetak dengan menggunakan saringan berukuran 20 mesh. Kemudian dilakukan pengovenan dengan tujuan menguapkan kandungan air dan pelarut organiknya. Suhu pengeringan adalah $40^{\circ} \mathrm{C}$ pada waktu 2 jam. Hasil kenampakan granul setelah pengeringan terdapat pada Gambar 3 .

\section{Gambar 3. Kenampakan Granul Biolarvasida (a) Tanpa Ekstrak Daun Beluntas; (b) Dengan Ekstrak Daun Beluntas}

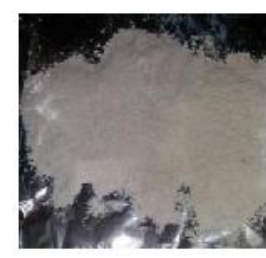

(a)

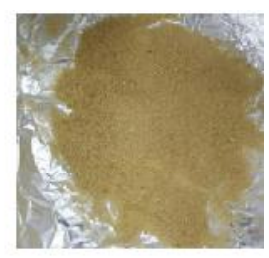

(b)
Pembuatan granul dilakukan dengan menggunakan ekstrak daun beluntas sebagai komponen utama biolarvasida dan pembutan granul tanpa ekstrak daun beluntas sebagai kontrol negatif yang selanjutnya digunakan untuk efikasi biolarvasida. Granul biolarvasida yang diperoleh memiliki warna kuning dan sukar larut 
dalam air. Jika dibandingkan dengan abate, granul biolarvasida ekstrak daun beluntas cenderung membentuk endapan didasar media penampungan air. Sedangkan granul tanpa ekstrak berwarna putih, secara fisika granul tanpa ekstrak lebih mudah dibentuk, lebih kaku dan rapuh serta lebih mudah larut dalam air.

Granul biolarvasida ekstrak daun beluntas pada konsentrasi bahan aktif 50 ppm larut sekitar $70 \%$ dalam air karena kemungkinan formulasi granul yang dipakai tidak menggunakan emulsifier. Hal ini terlihat masih ada sekitar 30\% yang terendapkan. Meskipun, abate juga memiliki sifat tidak larut dalam air akan tetapi proses pelepasan zat aktifnya lebih baik dibandingkan dengan granul biolarvasida ekstrak daun beluntas.
Uji stabilitas granul biolarvasida dilakukan untuk mengetahui waktu paruh serta kadaluarsa obat sediaan padat. Uji stabilitas dilakukan sesuai standar WHO. Larutan blangko yang digunakan pada uji stabilitas adalah air. Sebelum dianalisa menggunakan spektrofotometer UVVis, granul biolarvasida disimpan pada temperatur 30,40 dan $50^{\circ} \mathrm{C}$ selama 150 menit dengan pengambilan sampel secara berkala setiap 30 menit untuk mengetahui pengaruh temperatur terhadap waktu paruh dan kadaluarsa obat sediaan padat. Panjang gelombang maksimum yang digunakan adalah $287 \mathrm{~nm}$ (Gambar 4).

Hasil uji stabilitas pada variasi suhu terdapat pada Tabel 2. Dari data tersebut terlihat bahwa orde reaksi hasil analisa

Gambar 4. Scanning Panjang Gelombang Granul 100 ppm

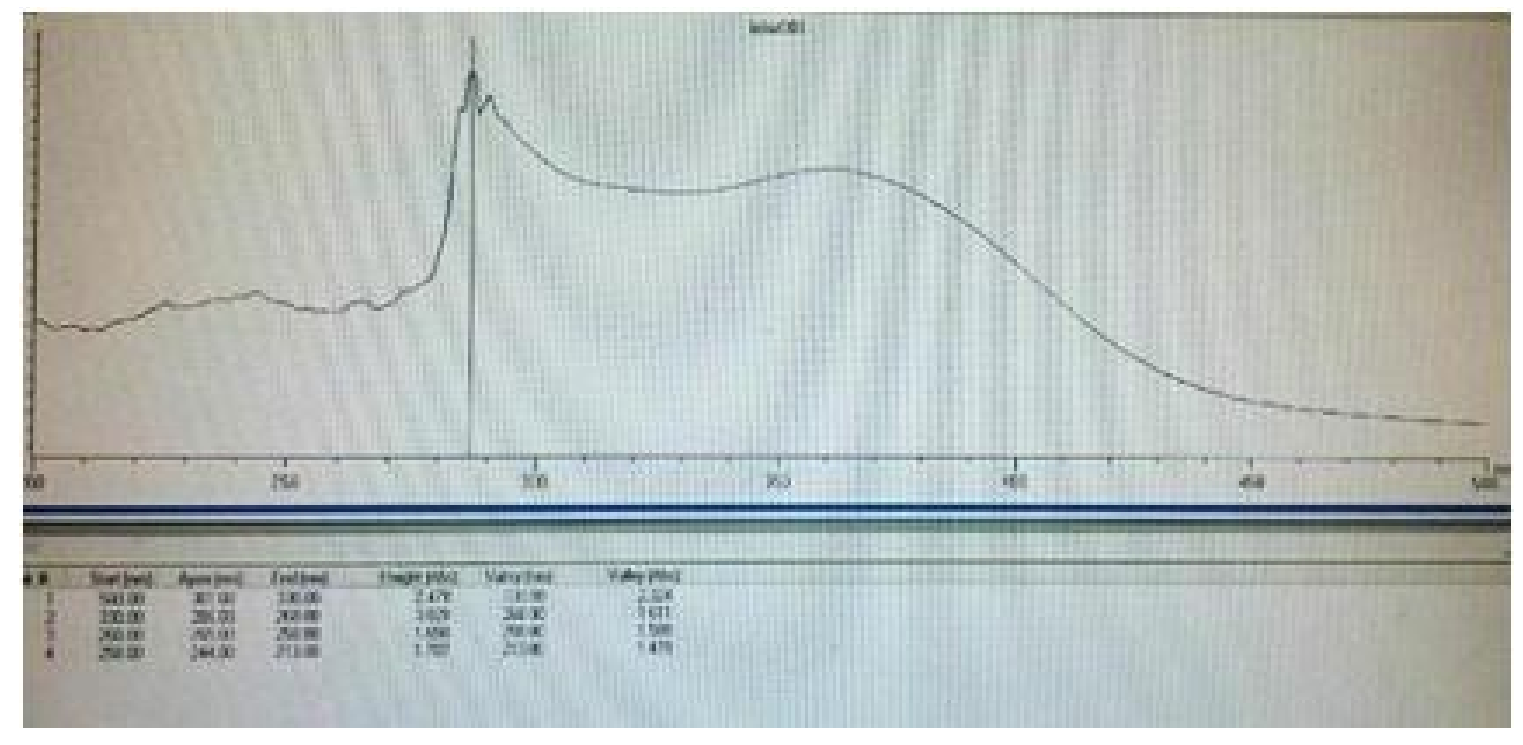


Jurnal Penelitian Saintek, Vol. 22, Nomor 1, April 2017

Tabel 2

Hasil Uji Stabilitas pada Variasi Suhu

\begin{tabular}{cclll}
\hline \multirow{2}{*}{ Suhu $\left(^{(}\right)$} & Nilai & \multicolumn{3}{c}{ Orde } \\
\cline { 3 - 5 } & & \multicolumn{1}{c}{0} & \multicolumn{1}{c}{1} & \multicolumn{1}{c}{2} \\
\hline \multirow{2}{*}{30} & $\mathrm{a}$ & $-2 \mathrm{E}-06$ & -0.0014 & 6.7084 \\
& $\mathrm{~b}$ & 0.0006 & -3.2347 & 1680.4 \\
& $\mathrm{r}^{2}$ & 0.9067 & 0.8969 & 0.8871 \\
40 & $\mathrm{a}$ & $-2.00 \mathrm{E}-06$ & -0.0013 & 4.8863 \\
& $\mathrm{~b}$ & 0.0007 & -3.1332 & 1337.2 \\
& $\mathrm{r}^{2}$ & 0.9973 & 0.994 & 0.9894 \\
50 & $\mathrm{a}$ & $6.00 \mathrm{E}-06$ & 0.0044 & -17.663 \\
& $\mathrm{~b}$ & 0.0002 & -3.5568 & 311.16 \\
& $\mathrm{r}^{2}$ & 0.6676 & 0.6322 & 0.5879 \\
\hline
\end{tabular}

stabilitas berada pada orde nol karena nilai regresi mendekati linear $\left(r^{2}=1\right)$. Pada konsentrasi $100 \mathrm{ppm}$ temperatur $30^{\circ} \mathrm{C}$ diperoleh waktu paruh granul biolarvasida adalah 46.981 menit. Waktu paruh menunjukkan waktu yang dibutuhkan granul untuk melepaskan zat aktif dan mengalami peluruhan partikel granul. Sedangkan waktu kadaluarsa yang diperoleh adalah 36.25 hari atau 1.208 bulan. Hal ini terjadi karena bahan penyusun granul merupakan bahan pangan (laktosa dan pati) yang mudah terdegradasi dan tidak menimbulkan efek bahaya bagi manusia. Selain itu, kelembapan udara penyimpanan juga akan mempengaruhi waktu kadaluarsa obat. Bahan aktif yang terkandung dalam granul biolarvasida juga bersifat biodegradabel, sehingga mudah terurai dalam temperatur ruang.

Efikasi biolarvasida dilakukan dengan membandingkan granul biolarvasida ekstrak daun beluntas, granul tanpa ekstrak (kontrol negatif) dan abate (kontrol positif). Uji biolarvasida dilakukan pada temperatur ruang. Larva yang diuji merupakan larva instar III dengan panjang larva mencapai (4 mm). Larva yang sehat dapat dilihat dari pergerakannya yang cepat dan lincah dalam air.

Hasil uji efikasi larvasida menggunakan abate disajikan pada Gambar 5. Gambar 5 menunjukkan kematian 100\% sejak penggunaan $50 \mathrm{ppm}$ dalam air yang berisi larva Aedes aegypti. Pelepasan zat aktif dalam abate berlangsung cepat, kurang dari 1 jam kontak abate dalam air sudah mampu membunuh 100\% larva Aedes aegypti. Kandungan zat aktif dalam abate bersifat sangat toksik terhadap larva nyamuk. Akan tetapi, abate merupakan senyawa yang bersifat organo fosfat sehingga berbahaya bagi manusia apabila mengkonsumsi air 
Gambar 5. Grafik Uji Efikasi Biolarvasida

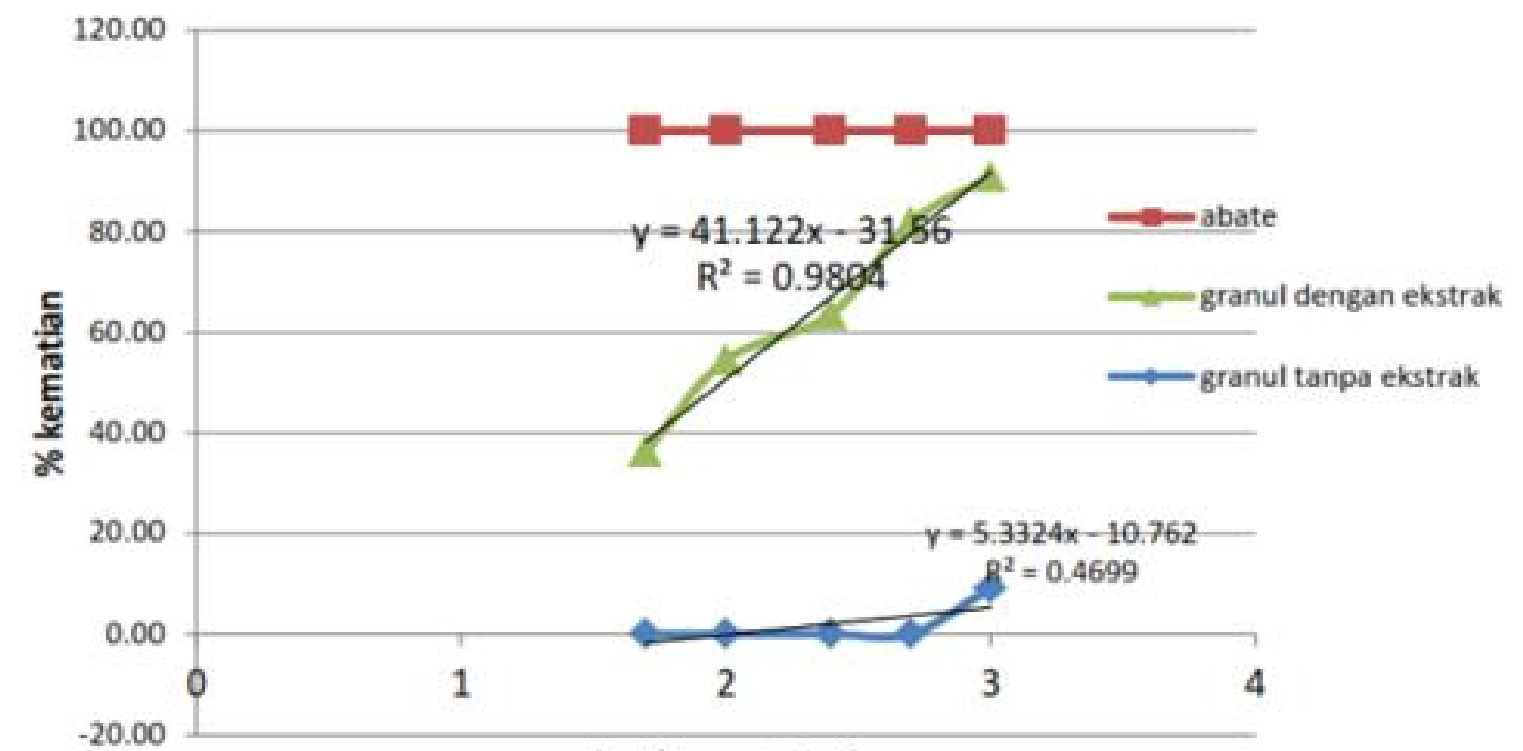

log konsentrasi

yang telah terkontamiasi abate dalam jangka panjang. Granul ekstrak daun beluntas bersifat sukar larut seperti abate, akan tetapi proses pelepasan zat aktifnya tidak sebaik abate. Hal ini ditunjukkan dengan $\mathrm{LC}_{50}$ pada granul dengan kandungan ektrak daun beluntas adalah 96,34 ppm. Sedangkan $\mathrm{LC}_{90}$ granul ekstrak daun beluntas adalah 905,1 ppm dengan persamaan regresi $\mathrm{y}=41.112 \mathrm{x}-31.56$ dan nilai $\mathrm{R}^{2}=0.9804$. Formulasi granul ektrak daun beluntas tidak berbahaya bagi manusia maupun ekosistem air karena mengandung bahan-bahan yang aman untuk dikonsumsi. Kondisi larva nyamuk Aedes aegypti setelah 24 jam kontak dengan ekstrak etil asetat. Sebagian besar larva nyamuk Aedes aegypti tenggelam pada dasar larutan. Kenampakan sampel uji terlihat ada yang terapung dalam kondisi hancur dan sebagian yang utuh terendapkan di bagian dasar tabung reaksi. Meskipun masih terlihat 2 larva yang masih bergerak lemah dari 15 larva yang diuji coba.

Hasil analisis GC-MS pada ekstrak etil asetat diperoleh data spektrum seperti pada Gambar 6. Dari hasil analisa GC-MS etil asetat diperoleh senyawa dominan yaitu 1-dodecanamine, sebesar 7,90\% dan asam quanat $9,90 \%$. Menurut penelitian yang telah dilakukan oleh Zhang et al. (2013) senyawa asam quanat mempunyai kemampuan sebagai antimikroba dan antifungi. Kemampuan inhibisi asam quanat pada pertumbuhan bakteri salmonella sp seperti S.aureus, B. thuringiensis, E. coli, S. enterica 
Gambar 6. Grafik Hasil Analisa GC-MS Ekstrak Etil Asetat

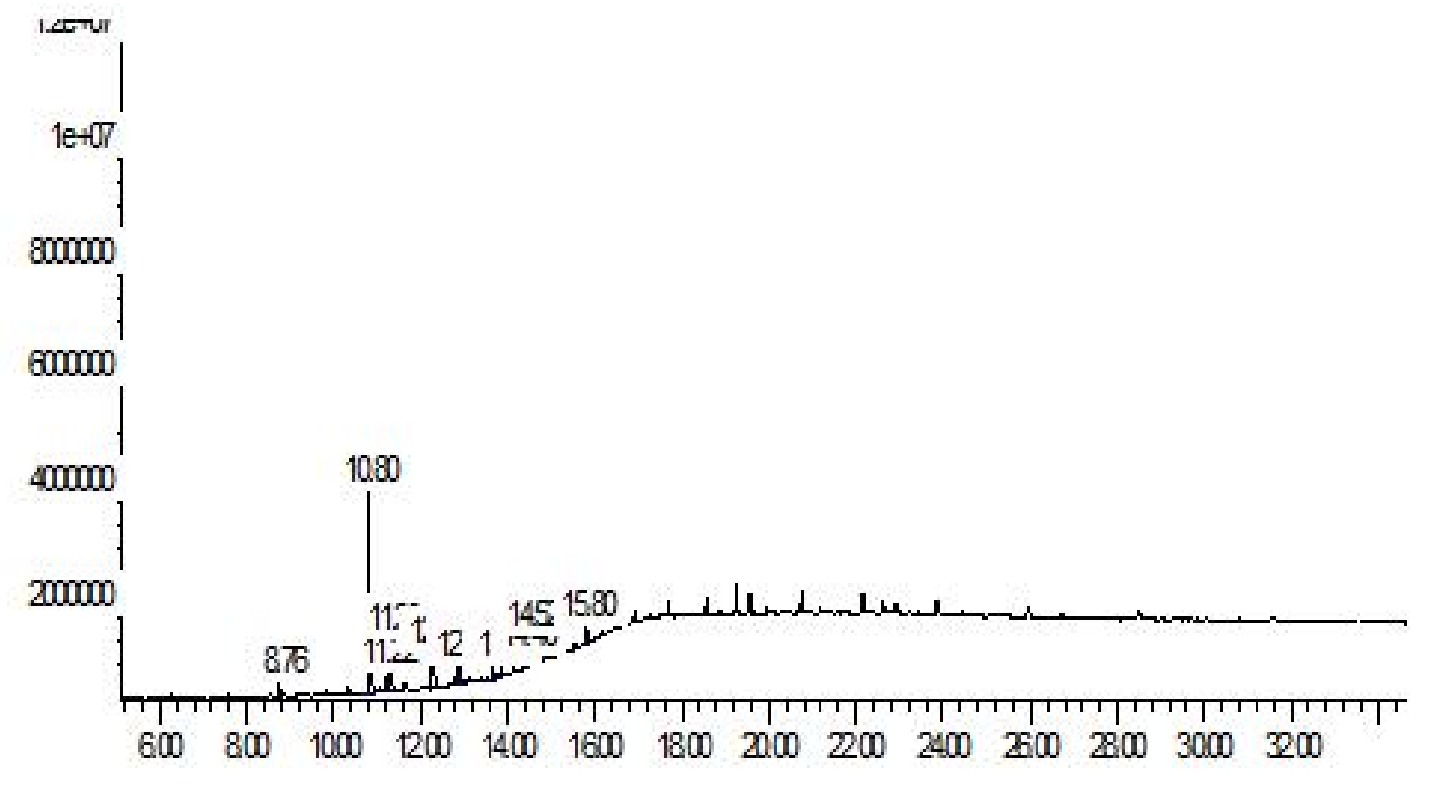

Tine- $\rightarrow$

dan S. dysenteria terjadi pada konsentrasi 7,5 M dan 14,7 M; melalui gangguan pada alat pencernaan dan pelarutan lipin pada badan bakteri terbelah menjadi dua yakni terapung dipermukaan dalam kondisi hancur daan terendapkan didasar tabung. Sementara itu kemampuan inhibisi asam quanat pada pertumbuhan jamur $M$. grisea terjadi pada konsentrasi 542,3 M. Sifat toksisitas asam quanat diduga menyebabkan kematian awal bagi larva. Bisa dilihat dari nilai $\mathrm{LC}_{50}$ sebesar 96,34 ppm yang tergolong sangat toksik. Maka sifat biolarvasida ekstrak etil asetat daun beluntas dengan nilai $\mathrm{LC}_{50}$ sebesar 96,34 ppm tergolong ekstrak yang sangat toksik bagi larva Aedes aegipty.

\section{SIMPULAN}

Dari hasil penelitian ini dapat disimpulkan bahwa Nilai $\mathrm{LC}_{50}$ ekstrak etil asetat daun beluntas adalah 105,79 ppm. Nilai $\mathrm{LC}_{50}$ yang diperoleh termasuk golongan biolarvasida aktif dan kontrol positif menggunakan abate memiliki nilai $\mathrm{LC}_{100}$ pada konsentrasi $100 \mathrm{ppm}$. Sementara itu, nilai $\mathrm{LC}_{50}$ pada granul dengan kandungan ektrak daun beluntas yang terbaik diperoleh nilai $96,34 \mathrm{ppm}$ dan nilai $\mathrm{LC}_{90}$ adalah 905.1 ppm. Kemampuan biolarvasida aktif ekstrak beluntas ini dikuatkan dengan hasil analisa GC-MS yang menunjukkan bahwa kandungan senyawa aktif biolarvasida dalam ekstrak etil asetat diduga asam quanat. 


\section{DAFTAR PUSTAKA}

Ardiansyah, L. N., \& Andarwulan, N. (2003). Aktivitas antimikroba ekstrak daun beluntas (Plucea indica L.) dan stabilitas aktivitasnya pada berbagai konsentrasi garam dan tingkat $\mathrm{pH}$. Jurnal Teknologi dan Industri Pangan 14(2), 90-97.

Bhawan, V. R., \& Nagar, A. (2012). Common protocol for uniform evalution of insectisides/bio-larvacides foruse in vector control. Indian Council of Medical Research. New Delhi.

Kardinan, A. (2011). Penggunaan pestisida nabati sebagai kearifan lokal dalam pengendalian hama tanaman menuju sistem pertanian organik. Jurnal Pengembangan Inovasi Pertanian, 4 (4), 262-278.
Kasus DBD Cilegon Tertinggi di Banten. (2004, Mei). Diunduh dari http:// www.radarbanten.com/read/berita/ 50/12209/.

Reiza, Z. (2010). Perbandingan penggunaan metode granulasi basah dan granulasi kering terhadap stabilitas zat aktif table paracetamol (Skripsi tidak diterbitkan). UMS, Surakarta.

Voight, R. (1994). Buku pelajaran teknologi farmasi (Edisi 5). Yogyakarta: UGM Press.

Zhang, M., Liu, W. X., Zheng, M. F., Xu, Q. L., Wan, F. H., Wang, J., ... \& Tan, J. W. (2013). Bioactive quinic acid derivatives from Ageratina adenophora. Molecules, 18(11), 14096-14104. 